This is a self-archived - parallel published version of this article in the publication archive of the University of Vaasa. It might differ from the original.

\title{
Factors Influencing Households' Intention to Adopt Solar PV: A Systematic Review
}

Author(s): Shakeel, Shah Rukh; Rajala, Arto

Title: $\quad$ Factors Influencing Households' Intention to Adopt Solar PV: A Systematic Review

Year: $\quad 2020$

Version: Accepted manuscript

Copyright (C)2020 Springer. This is a post-peer-review, pre-copyedit version of an article published in Advances in Human Factors, Business Management and Leadership. AHFE 2020. The final authenticated version is available online at: http://dx.doi.org/10.1007/978-3-030-50791-6_36

\section{Please cite the original version:}

Shakeel, S. R. \& Rajala, A. (2020). Factors Influencing Households' Intention to Adopt Solar PV: A Systematic Review. In: Kantola, J., Nazir, S. \& Salminen, V. (eds.) Advances in Human Factors, Business Management and Leadership Proceedings of the AHFE 2020 Virtual Conferences on Human Factors, Business Management and Society, and Human Factors in Management and Leadership, July 16-2O, 202O, USA, 282-289. Advances in intelligent systems and computing, vol. 1209. Cham: Springer. http://dx.doi.org/10.1007/978-3-03050791-6_36 


\title{
Factors Influencing Households' Intention to Adopt Solar PV: A Systematic Review
}

\author{
Shah Rukh Shakeel ${ }^{1(\otimes)}$ and Arto Rajala ${ }^{2}$ \\ ${ }^{1}$ School of Marketing and Communication, and Innovation and Entrepreneurship InnoLab, \\ University of Vaasa, Wolffintie 34, 65200 Vaasa, Finland \\ shah.rukh.shakeel@uwasa.fi \\ 2 School of Marketing and Communication, University of Vaasa, \\ Wolffintie 34, 65200 Vaasa, Finland \\ arto.rajala@uwasa.fi
}

\begin{abstract}
Rising energy needs, concerns of energy security, mitigating greenhouse gas emissions, climate change phenomenon and a push to utilize indigenous sources for energy generation purposes has encouraged the use of solar photovoltaics (PV). The technological advancements of the recent past, improvement in technologies' performance, reduction in the prices, policy and regulatory support, and its applicability at household level has made solar energy as a preferred form of energy generation. However, despite its rapid diffusion, it is widely believed that its current application is insignificant compared to its potential. This leads us to ask why solar PV has not been adopted to the level it should have. The existing literature has highlighted a number of factors affecting solar PV adoption. This paper systematically reviews the literature to identify the factors that have been instrumental to solar PV adoption. By exploring the Scopus database, this research identifies 39 articles matching the study objectives. Findings of this research will help academics, technology companies and policymakers in understanding the factors influencing the process and proposing solutions to address these.
\end{abstract}

Keywords: Adoption behaviour · Intentions to adopt · Barriers and facilitators · Systematic review · Solar PV

\section{Introduction}

The climate change phenomenon, the concerns of energy security and the issues associated with the conventional energy sources has triggered an inevitable need to transform energy sector. The existing energy infrastructure - energy production and consumption - has played an important role in the development of modern economies by assisting countries in meeting their primary energy needs. However, the rise in average global temperature, the increase in greenhouse gas emissions, sustainable use of conventional hydrocarbons and growing energy demand has highlighted the need to develop means through which the energy needs can be fulfilled without compromising the environment.

(C) The Editor(s) (if applicable) and The Author(s), under exclusive license to Springer Nature Switzerland AG 2020

J. I. Kantola et al. (Eds.): AHFE 2020, AISC 1209, pp. 282-289, 2020.

https://doi.org/10.1007/978-3-030-50791-6_36 
The effective utilization of renewable energy sources renders an excellent opportunity to meet future energy needs in a sustainable and environmentally friendly manner [1].

Renewable energy sources has become a preferred choice due to their positive effects on the environment, their infinite nature and the role they can play in strengthening a county's energy security [2]. The development of latest technologies and a favourable policy regime has made it possible to efficiently utilize the available resources of energy generation purposes. REN21 affirms that the use of renewable sources in power generation has grown in recent years. Solar and wind energy alone have generated $151 \mathrm{GW}$ electricity during 2018 [3]. An advantage that solar energy gets over other renewables is that in addition to commercial application, it provides individuals an opportunity to harness the potential for household purposes. A number of countries across globe are encouraging consumers to adopt this environmentally friendly mean of energy generation. The rationale behind the choice is that the self-production will reduces consumers' dependency on the grid electricity as well as the access energy can be transmitted back to the grid, thus offers an opportunity of becoming energy producer as well.

Despite the enormous potential and benefits, the utilization of solar energy at household level is less than desired. A number of studies have highlighted the factors affecting the diffusion of solar photovoltaics for household purposes. This paper systematically reviews the literature to identify the factors that have influenced solar PV adoption at household level.

\section{Methodology}

A successful systematic review is based on the clarity of the research question, keywords developed to assist the search, the databases explored to find relevant literature and researchers' ability to extract and present information in a manner that it highlight valuable insights to the readers as well as offers future research direction. Considering the objective of the paper i.e. to study the factors influencing intentions to adopt solar PV for household use, the following keywords were incorporated to ensure that the search extract desired articles. The keywords (factor OR factors OR antecedents OR drivers OR barriers OR impediments OR determinants OR traits) AND (affect OR affecting OR influence OR influencing OR examine OR examining) AND (intention OR intentions OR “intentions to use" OR use OR adoption OR "intentions to adopt" OR adopt OR accept* OR application) AND ("renewable energy technology*" OR "Solar energy" OR "Solar PV" OR "Solar Photovoltaic*” OR "Photovoltaics" OR "solar rooftop*” OR "rooftops") AND ("household" OR "home" OR "house" OR "private dwellings" OR "building"). The SCOPUS database was selected to search articles. The initial search yield 187 articles in total. The title, abstract and keywords were screened at the first phase to identify if the articles fits the criteria. In the cases, where initial screening did not provide sufficient information on inclusion or exclusion, full text was consulted to determine the eligibility. The final list included 39 articles. The list of articles is presented in the Table 1 . 
Table 1. Complete list of papers included in this review

\begin{tabular}{|c|c|c|c|c|c|c|c|}
\hline No & Authors & $\begin{array}{l}\text { Data } \\
\text { collection }\end{array}$ & $\begin{array}{l}\text { Theory / } \\
\text { Framework }^{+}\end{array}$ & No & Authors & $\begin{array}{l}\text { Data } \\
\text { collection }\end{array}$ & $\begin{array}{l}\text { Theory / } \\
\text { Framework }^{+}\end{array}$ \\
\hline 1 & Bach et al. [5] & INT & $\mathrm{EnCF}$ & 21 & $\begin{array}{l}\text { Shakeel \& } \\
\text { Rahman [6] }\end{array}$ & SR & ТРВ \\
\hline 2 & $\begin{array}{l}\text { Mundaca \& } \\
\text { Samahita [7] }\end{array}$ & WSR & NA & 22 & $\begin{array}{l}\text { Engelken et al. } \\
{[8]}\end{array}$ & WSR & ТPB \\
\hline 3 & $\begin{array}{l}\text { Kapoor \& } \\
\text { Dwivedi [9] }\end{array}$ & SR & DOI & 23 & $\begin{array}{l}\text { Walta-s et el. } \\
{[10]}\end{array}$ & FG & NA \\
\hline 4 & Best et al. [11] & SR & NA & 24 & Bashiti et al. [12] & SR & NA \\
\hline 5 & $\begin{array}{l}\text { Alrashoud \& } \\
\text { Tokimatsu [13] }\end{array}$ & WSR & DOI & 25 & $\begin{array}{l}\text { Qureshi et al. } \\
\text { [14] }\end{array}$ & INT & DOI \\
\hline 6 & $\begin{array}{l}\text { Kastner \& } \\
\text { Wittaibarg [15] }\end{array}$ & SR, OB & SI & 26 & Dharshing [16] & PD & NA \\
\hline 7 & Zanda- et al. [17] & SR & $\mathrm{ChM}$ & 27 & $\begin{array}{l}\text { Jayaraman et al. } \\
\text { [18] }\end{array}$ & SR & ТPB \\
\hline 8 & $\begin{array}{l}\text { Arroyo \& } \\
\text { Carrete [19] }\end{array}$ & SR & GoFT & 28 & $\begin{array}{l}\text { Briguglio \& } \\
\text { Formosa [20] }\end{array}$ & SD & NA \\
\hline 9 & Abreu et al. [21] & SR & ТPB & 29 & $\begin{array}{l}\text { Baharoon et al. } \\
\text { [22] }\end{array}$ & SR & NA \\
\hline 10 & Lee \& Hong [23] & SD & ABM, GIS & 30 & $\begin{array}{l}\text { Kansal \& } \\
\text { Pathania [24] }\end{array}$ & SR & NA \\
\hline 11 & Lu et al. [25] & SR & NA & 31 & $\begin{array}{l}\text { Schaffa- \& Brun } \\
\text { [26] }\end{array}$ & SD & NA \\
\hline 12 & Afroz et al. [27] & SR & NA & 32 & Palmar et al. [28] & SD & $\mathrm{ABM}$ \\
\hline 13 & $\begin{array}{l}\text { Graziano et al. } \\
\text { [29] }\end{array}$ & SD & NA & 33 & Sigrin et al. [30] & SR & NA \\
\hline 14 & $\begin{array}{l}\text { Aggarwal et al. } \\
\text { [31] }\end{array}$ & SR & TPB, UTAUT & 34 & $\begin{array}{l}\text { Vasseur \&. } \\
\text { Kemp [32] }\end{array}$ & SR & NA \\
\hline 15 & Tsaur \& Lin [33] & SR & TAM, TPB & 35 & $\begin{array}{l}\text { Sriwannawita \& } \\
\text { Laestadiusb [34] }\end{array}$ & INT, OB & NA \\
\hline 16 & $\begin{array}{l}\text { Wolske et al. } \\
\text { [35] }\end{array}$ & WSR & NA & 36 & $\begin{array}{l}\text { Kapoor et al. } \\
{[36]}\end{array}$ & LTR & CnMD \\
\hline 17 & Bondio et al. [37] & SR & DOI & 37 & $\begin{array}{l}\text { Komatsu et al. } \\
{[38]}\end{array}$ & SR & NA \\
\hline I8 & $\begin{array}{l}\text { Srivastava \& } \\
\text { Mehendar [39] }\end{array}$ & SR & TPB & 38 & Schelly [40] & SD & NA \\
\hline 19 & Rahut et al. [41] & SD & NA & 39 & $\begin{array}{l}\text { McEachem \& } \\
\text { Hanson [42] }\end{array}$ & SR & NA \\
\hline 20 & $\begin{array}{l}\text { Jayaw eera et al. } \\
\text { [43] }\end{array}$ & GIS & NA & & & & \\
\hline
\end{tabular}

*INT (Interview's), WSR (Web-Survey), SR (Survey), OB (Obsavation), SD (Secondary Data), PD (Panel Data), LTR (Literature), FG (Focus group) +EnCF (Energy cluster framework), NA (Not Applicable), DOI (Diffusion of innovations), SI (Social influences), ChM (Choice Model), GoFT (Goal framing theory), TPB (theory of planned behaviour), ABM (Agent based model), GIS (Geographic informafion system), UTAUT (Unified theory of acceptance and use technology), TAM (technology acceptance model), CnMD (Conceptual model) 


\section{Results}

\subsection{Distribution}

The 39 articles included in the review has been published in 23 different journals. Renewable and Sustainable Energy Reviews lead the publications with six articles followed by Energy Research and Social Science and Energy Policy with five articles each, whereas sustainability has published four articles. The publishing journal covered topics related to energy, policy matters, sustainability, social sciences, business studies and technology related issues. The earliest paper included in the review was published in the year 2008 while the latest paper was published as recently as January 2020, the month this review was conducted. The distribution of the publications suggests that almost $72 \%$ of the papers were published during 2017-2020 while 23\% were published during 2013-2016 and only 5\% were published during 2008-2012. The rising number of publications in the domain signifies researchers' interest in the field as well as highlights the importance of the subject in the recent times. This amplified interest can also be attributed to the recent advancement in solar PV in terms of technology's performance, reduction in cost, improvement in efficiency and the supportive policies the counties have adopted for the development and diffusion of renewable energy technologies. The analysis of geographical distribution reveals that around $38 \%$ of the studies were conducted in the Asian context followed by $23 \%$ and $15 \%$ in Europe and North America respectively. The country wise ranking reveals that the USA is the leading country with five articles, followed by Germany with four articles, whereas three articles were published in both India and Australia.

\subsection{Methods}

The analysis of methods reveals that the research done in this field has primarily been deductive in nature with over $80 \%$ of the papers employing quantitative methods. The two thirds of the quantitative studies have used survey questionnaires for primary data collection while the remaining $20 \%$ have relied on data collected by various national/international agencies or have used the information gathered through geographical information system. Three of the total five qualitative studies have used semi-structured interviews for data collection, while one study employed focus group approach, while the fifth paper proposed a conceptual model using secondary data.

The quantitative studies can be categorized into theoretical and atheoratical. The theoretical papers have relied on the established theoretical lenses rooted from innovation management, psychology and social sciences literature. An overwhelming majority of the studies have used theory of reasoned action (TRA), theory of planned behaviour (TPB), diffusion of innovations (DOI), technology acceptance model (TAM), and unified theory of acceptance and use of technology (UTAUT). These theoretical frameworks have been employed in multiple fields to study technology adoption in different contexts [4]. However, the review highlights that most of the studies have extended the original framework by integrating new variables or have combined two or more theories, or adopted their constructs to investigate the problem. The rational of combining theories/extending original framework has been to integrate new variables that could have an impact on the adoption of solar PV. 


\subsection{Factors Influencing the Adoption Behavior}

This systematic review affirms that the adoption of solar PV can be influenced by a number of factors. The factors can be divided into demographic, personal, social, technical, economic and external factors. The demographic factors concern with individual's age, gender, education, occupation, income, marital status, house size, house type, number of residents, ownership status and condition of building. The personal factors refer to an individual' attitude towards the environment, interest in environmental issues, level of motivation, expectations, perceived benefits, knowledge about the technology, willingness to adopt, intentions and perceived behavioural control.

In addition to individual's personal attributes, the effect of social factors on the adoption behaviour is apparent. The scholars have studied this by considering if the neighbours have installed solar PV at their houses, the overall installation in the locality as well as effect of visibility and observability of the technology. The adoption is also found to be affected by the complex nature of solar PV, consumers' perceived ease of use, their understanding of its usefulness, compatibility, relative advantage, risks associated with the use and after-sale repair and maintenance services are some of the major technical factors. The economic considerations are found to be the most important factors influencing the adoption. The high cost of the technology, the amount needed to be paid up front, financing options, the return on investment, the saving it could yield during the life span of the technology and reduction in the energy bills are some of the factors have impact on the adoption. The external factors include the market price of energy, subsidies, the regulations building owners needs to comply with and incentives on installation of energy generation.

\section{References}

1. Lovins, A.: Reinventing Fire: Bold Business Solutions for the New Energy Era. Chelsea Green Publishing, Vermont (2011)

2. Shakeel, S.R.: Commercialization of Renewable Energy Technologies: A study of Socioeconomic, Technical and Regulatory factors in Finland and Pakistan. Acta Wasaensia, vol. 430. University of Vaasa (2019)

3. REN21: Renewables 2019 Global Status Report, Paris (2019)

4. Chen, M.F.: Extending the theory of planned behavior model to explain people's energy savings and carbon reduction behavioral intentions to mitigate climate change in Taiwanmoral obligation matters. J. Clean. Prod. 112, 1746-1753 (2016). https://doi.org/10.1016/j. jclepro.2015.07.043

5. Bach, L., Hopkins, D., Stephenson, J.: Solar electricity cultures: household adoption dynamics and energy policy in Switzerland. Energy Res. Soc. Sci. 63, 101395 (2020). https://doi.org/ 10.1016/j.erss.2019.101395

6. Shakeel, S.R., Rahman, S.U.: Towards the establishment of renewable energy technologies' market: an assessment of public acceptance and use in Pakistan. J. Renew. Sustain. Energy. 10, 045907(1-15) (2018). https://doi.org/10.1063/1.5033454

7. Mundaca, L., Samahita, M.: What drives home solar PV uptake? Subsidies, peer effects and visibility in Sweden. Energy Res. Soc. Sci. 60, 101319 (2020). https://doi.org/10.1016/j.erss. 2019.101319 
8. Engelken, M., Römer, B., Drescher, M., Welpe, I.: Why homeowners strive for energy selfsupply and how policy makers can influence them. Energy Policy 117, 423-433 (2018). https:// doi.org/10.1016/j.enpol.2018.02.026

9. Kapoor, K.K., Dwivedi, Y.K.: Sustainable consumption from the consumer's perspective: antecedents of solar innovation adoption. Resour. Conserv. Recycl. 152, 104501 (2020). https://doi.org/10.1016/j.resconrec.2019.104501

10. Walters, J., Kaminsky, J., Gottschamer, L.: A systems analysis of factors influencing household solar PV adoption in Santiago. Chile. Sustainability 10, 1257 (2018). https://doi.org/10.3390/ su10041257

11. Best, R., Burke, P.J., Nishitateno, S.: Understanding the determinants of rooftop solar installation: evidence from household surveys in Australia. Aust. J. Agric. Resour. Econ. 63, 922-939 (2019). https://doi.org/10.1111/1467-8489.12319

12. Bashiri, A., Alizadeh, S.H.: The analysis of demographics, environmental and knowledge factors affecting prospective residential PV system adoption: a study in Tehran. Renew. Sustain. Energy Rev. 81, 3131-3139 (2018). https://doi.org/10.1016/j.rser.2017.08.093

13. Alrashoud, K., Tokimatsu, K.: Factors influencing social perception of residential solar photovoltaic systems in Saudi Arabia. Sustainability 11, 5259 (2019). https://doi.org/10.3390/ su11195259

14. Qureshi, T.M., Ullah, K., Arentsen, M.J.: Factors responsible for solar PV adoption at household level: a case of Lahore, Pakistan. Renew. Sustain. Energy Rev. 78, 754-763 (2017). https://doi.org/10.1016/j.rser.2017.04.020

15. Kastner, I., Wittenberg, I.: How measurements "affect" the importance of social influences on household's photovoltaic adoption - a German case study. Sustainability 11, 5175 (2019). https://doi.org/10.3390/su11195175

16. Dharshing, S.: Household dynamics of technology adoption: a spatial econometric analysis of residential solar photovoltaic (PV) systems in Germany. Energy Res. Soc. Sci. 23, 113-124 (2017). https://doi.org/10.1016/j.erss.2016.10.012

17. Zander, K.K., Simpson, G., Mathew, S., Nepal, R., Garnett, S.T.: Preferences for and potential impacts of financial incentives to install residential rooftop solar photovoltaic systems in Australia. J. Clean. Prod. 230, 328-338 (2019). https://doi.org/10.1016/j.jclepro.2019.05.133

18. Jayaraman, K., Paramasivan, L., Kiumarsi, S.: Reasons for low penetration on the purchase of photovoltaic (PV) panel system among Malaysian landed property owners. Renew. Sustain. Energy Rev. 80, 562-571 (2017). https://doi.org/10.1016/j.rser.2017.05.213

19. Arroyo, P., Carrete, L.: Motivational drivers for the adoption of green energy: the case of purchasing photovoltaic systems. Manage. Res. Rev. 42, 542-567 (2019). https://doi.org/10. 1108/MRR-02-2018-0070

20. Briguglio, M., Formosa, G.: When households go solar: determinants of uptake of a photovoltaic scheme and policy insights. Energy Policy 108, 154-162 (2017). https://doi.org/10. 1016/j.enpol.2017.05.039

21. Abreu, J., Wingartz, N., Hardy, N.: New trends in solar: a comparative study assessing the attitudes towards the adoption of rooftop PV. Energy Policy 128, 347-363 (2019). https://doi. org/10.1016/j.enpol.2018.12.038

22. Baharoon, D.A., Rahman, H.A., Fadhl, S.O.: Personal and psychological factors affecting the successful development of solar energy use in Yemen power sector: a case study. Renew. Sustain. Energy Rev. 60, 516-535 (2016). https://doi.org/10.1016/j.rser.2016.01.004

23. Lee, M., Hong, T.: Hybrid agent-based modeling of rooftop solar photovoltaic adoption by integrating the geographic information system and data mining technique. Energy Convers. Manage. 183, 266-279 (2019). https://doi.org/10.1016/j.enconman.2018.12.096

24. Kansal, B., Pathania, A.K.: Evaluation of consumer acceptance and satisfaction from solar energy products. Prabandhan Indian J. Manage. 9, 45-52 (2016). https://doi.org/10.17010/ pijom/2016/v9i12/107011 
25. Lu, Y., Chang, R., Shabunko, V., Lay Yee, A.T.: The implementation of building-integrated photovoltaics in Singapore: drivers versus barriers. Energy 168, 400-408 (2019). https://doi. org/10.1016/j.energy.2018.11.099

26. Schaffer, A.J., Brun, S.: Beyond the sun - Socioeconomic drivers of the adoption of smallscale photovoltaic installations in Germany. Energy Res. Soc. Sci. 10, 220-227 (2015). https:// doi.org/10.1016/j.erss.2015.06.010

27. Afroz, R., Tudin, R., Morshed, M.N., Duasa, J., Muhibbullah, M.: Developing a shariahcompliant equity-based crowdfunding model towards a Malaysian low-carbon consumer society. Malays. J. Consum. Fam. Econ. 22s2, 185-202 (2019)

28. Palmer, J., Sorda, G., Madlener, R.: Modeling the diffusion of residential photovoltaic systems in Italy: an agent-based simulation. Technol. Forecast. Soc. Change 99, 106-131 (2015). https://doi.org/10.1016/j.techfore.2015.06.011

29. Graziano, M., Fiaschetti, M., Atkinson-Palombo, C.: Peer effects in the adoption of solar energy technologies in the United States: an urban case study. Energy Res. Soc. Sci. 48, 75-84 (2019). https://doi.org/10.1016/j.erss.2018.09.002

30. Sigrin, B., Pless, J., Drury, E.: Diffusion into new markets: evolving customer segments in the solar photovoltaics market. Environ. Res. Lett. 10, 084001 (2015). https://doi.org/10.1088/ 1748-9326/10/8/084001

31. Aggarwal, A.K., Syed, A.A., Garg, S.: Diffusion of residential RT solar - is lack of funds the real issue? Int. J. Energy Sect. Manage. (2019). https://doi.org/10.1108/IJESM-02-20190004

32. Vasseur, V., Kemp, R.: The adoption of PV in the Netherlands: a statistical analysis of adoption factors. Renew. Sustain. Energy Rev. 41, 483-494 (2015). https://doi.org/10.1016/j.rser.2014. 08.020

33. Tsaur, R.-C., Lin, Y.-H.: Exploring the consumer attitude of building-attached photovoltaic equipment using revised technology acceptance model. Sustainability 10, 4177 (2018). https:// doi.org/10.3390/su10114177

34. Sriwannawita, P., Laestadiusb, S.: Determinants of the diffusion of solar home systems: case study among low-income inhabitants in Bangladesh. Energy Environ. 26, 803-816 (2015). https://doi.org/10.1260/0958-305X.26.5.803

35. Wolske, K.S., Todd, A., Rossol, M., McCall, J., Sigrin, B.: Accelerating demand for residential solar photovoltaics: can simple framing strategies increase consumer interest? Glob. Environ. Change 53, 68-77 (2018). https://doi.org/10.1016/j.gloenvcha.2018.08.005

36. Kapoor, K.K., Dwivedi, Y.K., Williams, M.D.: Examining consumer acceptance of green innovations using innovation characteristics: a conceptual approach. Int. J. Technol. Manage. Sustain. Dev. 13, 135-160 (2014). https://doi.org/10.1386/tmsd.13.2.135_1

37. Bondio, S., Shahnazari, M., McHugh, A.: The technology of the middle class: understanding the fulfilment of adoption intentions in Queensland's rapid uptake residential solar photovoltaics market. Renew. Sustain. Energy Rev. 93, 642-651 (2018). https://doi.org/10.1016/j. rser.2018.05.035

38. Komatsu, S., Kaneko, S., Shrestha, R.M., Ghosh, P.P.: Nonincome factors behind the purchase decisions of solar home systems in rural Bangladesh. Energy. Sustain. Dev. 15, 284-292 (2011). https://doi.org/10.1016/j.esd.2011.03.003

39. Srivastava, C., Mahendar, G.: Intention to adopt sustainable energy: applying the theory of planned behaviour framework. Indian J. Mark. 48, 20-33 (2018). https://doi.org/10.17010/ ijom/2018/v48/i10/132325

40. Schelly, C.: Testing residential solar thermal adoption. Environ. Behav. 42, 151-170 (2010). https://doi.org/10.1177/0013916508327867

41. Rahut, D.B., Mottaleb, K.A., Ali, A., Aryal, J.: The use and determinants of solar energy by sub-saharan African households. Int. J. Sustain. Energy 37, 718-735 (2017). https://doi.org/ $10.1080 / 14786451.2017 .1323897$ 
42. McEachern, M., Hanson, S.: Socio-geographic perception in the diffusion of innovation: solar energy technology in Sri Lanka. Energy Policy 36, 2578-2590 (2008). https://doi.org/ 10.1016/j.enpol.2008.03.020

43. Jayaweera, N., Jayasinghe, C.L., Weerasinghe, S.N.: Local factors affecting the spatial diffusion of residential photovoltaic adoption in Sri Lanka. Energy Policy 119, 59-67 (2018). https://doi.org/10.1016/j.enpol.2018.04.017 